\title{
КОНЦЕПЦІЯ ВІКОВИХ ОСОБЛИВОСТЕЙ ХРОНОРИТМОЛОГІЧНИХ ПЕРЕБУДОВ ФУНКЦІЇ НИРОК ЗА УМОВ КАДМІЄВОЇ ТА СВИНЦЕВОЇ ІНТОКСИКАЦІЇ
}

\section{Гордіснко В. В., Перепелиця О. О.}

\section{ВСТУП}

Інтенсивне забруднення навколишнього середовища породжує питання про те, наскільки організм людини здатний протистояти зростаючим хімічним навантаженням, якими $\epsilon$ його потенційні можливості і яким чином їх варто враховувати при пошуку засобів профілактики й лікування отруєнь. На жаль, темпи розвитку цивілізації призводять до відставання процесів біологічного пристосування живих організмів у середовищі їх проживання в онто- і філогенезі від швидкості змін, які відбуваються в ньому. Як глобальні забруднювачі навколишнього середовища, свинець і кадмій залишаються в центрі уваги токсикологів, гігієністів, екологів ${ }^{1,2,3}$. Оскільки реакція організму в різних вікових груп зумовлена особливостями їх адаптаційнопристосувальних механізмів, пріоритетними напрямками в токсикологічних дослідженнях $є$ віковий аспект проблеми ${ }^{4,5}$, виявлення ранніх ознак патологічних реакцій в організмі за тривалого надходження токсикантів у дозах малої інтенсивності.

Поряд із цим, усе більшої актуальності набуває нове перспективне спрямування, яке поглиблює нашу уяву про механізми фізіологічних i патологічних процесів в організмі - хронобіологія, хрономедицина,

\footnotetext{
${ }^{1}$ Повякель Л.І. та ін. Важкі метали як фактор ризику для здоров'я людини та довкілля при поводженні з відходами електричного та електронного обладнання (огляд літератури). Сучасні проблеми токсикології, харчової та хімічної безпеки. 2015. № 1-2. С. 41-49.

2 Арустамян О.М., Ткачишин В.С., Алексійчук О.Ю. Вплив сполук кадмію на організм людини. Медицина неотложных состояний. 2016. № 7. С. 109-114.

3 Апихтіна О.Л., Козлов К.П. Динаміка накопичення кадмію у внутрішніх органах щурів після тривалого введення хлориду кадмію та наночастинок сульфіду кадмію різного розміру. Медичні перспективи. 2017. № 22(2). С. 4-9.

${ }^{4}$ Трахтенберг I.M. Токсичність і вік: проблема стара та нова. Нариси вікової токсикології. Київ : Авіцена, 2005. С. 10-17.

5 Трахтенберг И.М., Коршун М.Н., Вербилов А.А. Возрастные особенности развития адаптации к токсическим воздействиям. Очерки возрастной токсикологии. Киев : Авиценна, 2004. С. 34-40
} 
хронотоксикологія, хронофармакологія ${ }^{6,7,8}$. Однак хронобіологічним дослідженням токсичного ураження важкими металами (BM) 3 урахуванням вікових особливостей організму приділяється недостатньо уваги. 3 огляду на вищенаведене, монографія присвячена віковим особливостям токсичної дії солей ВМ - свинцю та кадмію на функціональний стан нирок 3 урахуванням хронобіологічної організації їх екскреторної, іонорегулювальної та кислотнорегулювальної функцій. Незважаючи на те, що провідним у монографії стало вивчення хронобіологічної організації функцій нирок у віковому аспекті, проведено системне дослідження тривалого впливу малих доз солей цих ВМ на показники загального стану організму тварин (маса тіла, масові коефіцієнти $\left(\mathrm{K}_{\mathrm{m}}\right)$ внутрішніх органів, розподіл і накопичення ВМ у тканинах організму, морфоструктура органів, стан про/антиоксидантного гомеостазу). 3 метою визначення загального впливу ВМ та можливі механізми їх токсичної дії на функціональний стан нирок в хронобіологічному аспекті досліджено також показники активності ферментів та морфоструктуру печінки, враховуючи важливу іiі роль не тільки у процесах детоксикації, а й, поряд із нирками, в регуляції водносольового гомеостазу (гепато-ренальний зв'язок).

\section{1. Вікові особливості тривалої дії на організм тварин низьких доз солей кадмію та свинцю}

Субхронічна інтоксикація статевонезрілих (СН3, 1,5 міс.) та статевозрілих (С3, 5 міс.) щурів солями ВМ у дозах малої інтенсивності (кадмію хлорид, 0,03 мг/кг $\left(3 \cdot 10^{-3}\right.$ DL50) ${ }^{9}$, свинцю ацетат, 0,3 мг/кг $\left(3,7 \cdot 10^{-5} \text { DL50 для щурів віком } 5 \text { міс., } 4 \cdot 10^{-5} \text { DL50 для щурів } 1,5 \text { міс. }\right)^{10}$, per os через зонд, 30 діб) негативно вплинула на приріст маси тіла тварин. Якщо за 30 діб природний приріст маси тіла в молодих СН3

${ }^{6}$ Пішак В.П., Булик Р.С. Молекулярно-генетичні маркери циркадіанних ритмів за фізіологічних умов. Буковинський медичний вісник. 2010. № 14 (2). 12-19.

7 Рапопорт С.И., Фролов В.А., Хетагурова Л. Г. Хронобиология и хрономедицина: руководство. Москва : ООО "Медицинское информационное агентство", 2012. 480 с.

8 Хронофармакология для врача, провизора и студента : учебник-справочник / под ред. С.М. Драговоз. Харьков : “Титул”, 2016. С. 376.

9 Кухарчук О.Л., Кокощук Г.І., Чала К.Н. Вплив гострої затравки щурів хлористим кадмієм на екскреторну функцію нирок за умов водного навантаження. Буковинський медичний вісник. 2001. № 5(2). С. 185-188.

${ }^{10}$ Янчук В.В., Власик Л.І. Вікові особливості розвитку хроноконцентраційного ефекту під впливом смертельних доз натрію нітрату та свинцю ацетату. Современные проблемы токсикологии. 2001. № 4. С. 37-38. 
щурів склав 58,5\% відносно вихідного рівня, то за дії кадмію хлориду маса тіла зросла лише на $16 \%$, а за свинцевої інтоксикації - на 12,6\%, тобто приріст маси тіла зменшився в 3,7 і 4,6 рази, відповідно. Маса тіла С3 тварин за дії кадмію хлориду зросла на 7,6\% (у контрольних на 17,2\%), а за дії солі свинцю стала меншою вихідного рівня.

Тривале надходження малих доз солей кадмію і свинцю позначилося й на $\mathrm{K}_{\mathrm{m}}$ органів-мішеней. За кадмієвої інтоксикації у СНЗ щурів $K_{\mathrm{m}}$ печінки зменшився на $18,5 \%$, за свинцевої - на $10,6 \%$. У С3 тварин металотоксикоз більше вплинув на $K_{\mathrm{m}}$ нирок, як основного екскреторного органа. За дії кадмію хлориду $\mathrm{K}_{\mathrm{m}}$ нирок зменшився на $28,8 \%$, за свинцевої інтоксикації - на $40,9 \%$ порівняно з $\mathrm{K}_{\mathrm{m}}$ органа контрольних тварин, що підтверджує нефротоксичність обраних нами ВМ. Поряд із цим, у С3 щурів збільшився $\mathrm{K}_{\mathrm{m}}$ серця, що, ймовірно, зумовлено негативним впливом солей кадмію й особливо свинцю на серцево-судинну систему ${ }^{112}$.

Уміст ВМ в організмі інтактних С3 щурів вірогідно вищий, ніж у СН3. Так, уміст катіонів кадмію в печінці С3 щурів більший у 8 разів, у мозку - в 4,3 рази, в скелетному м'язі - в 3,1 рази, нирках - в 1,3 рази. Вміст катіонів свинцю в печінці С3 тварин вищий в 7,2 рази, в нирках в 3,2 рази, в серці - в 1,7 рази. У СН3 тварин найвищий вміст кадмію i свинцю спостерігається в нирках (табл. 1). За умов надлишкового (протиприродного) надходження в організм солей ВМ відбувається прогресивне накопичення катіонів відповідних металів в організмі тварин різного віку 3 порушенням їх природного розподілу у тканинах. Після 30добового введення кадмію хлориду вміст катіонів кадмію в нирках СНЗ тварин зріс у 17 разів, у печінці - у 8,6 рази. У СЗ тварин на тлі вищого, ніж у СНЗ вмісту, інтенсивність накопичення металу в органах-мішенях нижча. Вміст катіонів кадмію в нирках зріс у 4,3 рази, в печінці - в 3,5 рази, в мозку - в 1,9 рази порівняно з інтактними С3 тваринами. У цілому накопичення катіонів кадмію в печінці С3 тварин за умов металотоксикозу втричі вище, ніж у СН3 тварин при градієнті тканинного вмісту у СН3 і С3 тварин: нирки > печінка > серце > скелетний м'яз > мозок.

11 Антоняк Г.Л. та ін. Екотоксикологічні аспекти впливу кадмію на організм людини і тварин. Медична хімія. 2007. № 9(3). С. 112-119.

12 Зербино Д.Д., Соломенчук Т.М. Свинец: поражения сосудистой системы. Український медичний часопис. 2002. 2(18). С. 79-83 
Таблиця 1

Вміст катіонів кадмію та свинцю (мг/кг) в органах щурів різного віку за тривалого (30 діб) надходження

в організм солі відповідного металу $(\mathrm{x} \pm \mathrm{Sx})$

\begin{tabular}{|c|c|c|c|c|c|}
\hline \multirow[b]{2}{*}{ Орган } & \multirow[b]{2}{*}{ Метал } & \multicolumn{2}{|c|}{ Статевонезрілі } & \multicolumn{2}{|c|}{ Статевозрілі } \\
\hline & & $\begin{array}{c}\text { Контроль } \\
(\mathbf{n}=7)\end{array}$ & $\begin{array}{l}\text { Дослід } \\
(\mathbf{n}=\mathbf{6})\end{array}$ & $\begin{array}{c}\text { Контроль } \\
(\mathbf{n}=7)\end{array}$ & $\begin{array}{l}\text { Дослід } \\
(\mathbf{n}=\mathbf{6})\end{array}$ \\
\hline \multirow{2}{*}{ हैं } & $\mathrm{Cd}^{2+}$ & $0,004 \pm 0,002$ & $0,009 \pm 0,0027$ & $\begin{array}{c}0,017 \pm 0,004 \\
\mathrm{p}_{1}<0,02\end{array}$ & $\begin{array}{c}0,032 \pm 0,0054 \\
\mathrm{p}<0,05 \\
\mathrm{p}_{1}<0,01\end{array}$ \\
\hline & $\mathrm{Pb}^{2+}$ & $0,10 \pm 0,036$ & $0,117 \pm 0,0228$ & $0,15 \pm 0,021$ & $0,126 \pm 0,03$ \\
\hline \multirow{2}{*}{ 苞 } & $\mathrm{Cd}^{2+}$ & $0,007 \pm 0,002$ & $\begin{array}{c}0,06 \pm 0,006 \\
\mathrm{p}<0,001\end{array}$ & $\begin{array}{c}0,056 \pm 0,018 \\
\mathrm{p}_{1}<0,02\end{array}$ & $\begin{array}{c}0,195 \pm 0,002 \\
\mathrm{p}<0,001 \\
\mathrm{p}_{1}<0,001\end{array}$ \\
\hline & $\mathrm{Pb}^{2+}$ & $0,011 \pm 0,001$ & $\begin{array}{c}0,088 \pm 0,006 \\
\mathrm{p}<0,001\end{array}$ & $\begin{array}{c}0,08 \pm 0,001 \\
\mathrm{p}_{1}<0,001\end{array}$ & $\begin{array}{c}0,319 \pm 0,037 \\
\mathrm{p}<0,001, \\
\mathrm{p}_{1}<0,001\end{array}$ \\
\hline \multirow{2}{*}{ 宽 } & $\mathrm{Cd}^{2+}$ & $0,067 \pm 0,002$ & $\begin{array}{c}1,137 \pm 0,028 \\
\mathrm{p}<0,001\end{array}$ & $\begin{array}{c}0,09 \pm 0,0012 \\
\mathrm{p}_{1}<0,001\end{array}$ & $\begin{array}{c}0,383 \pm 0,0015 \\
\mathrm{p}<0,001 \\
\mathrm{p}_{1}<0,001\end{array}$ \\
\hline & $\mathrm{Pb}^{2+}$ & $0,11 \pm 0,027$ & $\begin{array}{c}0,394 \pm 0,039 \\
\mathrm{p}<0,001\end{array}$ & $\begin{array}{c}0,35 \pm 0,023 \\
\mathrm{p}_{1}<0,001\end{array}$ & $\begin{array}{l}0,93 \pm 0,031 \\
\mathrm{p}<0,001 \\
\mathrm{p}_{1}<0,001\end{array}$ \\
\hline \multirow{2}{*}{ نั } & $\mathrm{Cd}^{2+}$ & $0,015 \pm 0,005$ & $0,019 \pm 0,006$ & $0,025 \pm 0,005$ & $0,034 \pm 0,004$ \\
\hline & $\mathrm{Pb}^{2+}$ & $0,03 \pm 0,003$ & $\begin{array}{c}0,069 \pm 0,018 \\
\mathrm{p}<0,01\end{array}$ & $\begin{array}{c}0,05 \pm 0,004 \\
\mathrm{p}_{1}<0,01\end{array}$ & $\begin{array}{c}0,117 \pm 0,009 \\
\mathrm{p}<0,001\end{array}$ \\
\hline \multirow{2}{*}{ 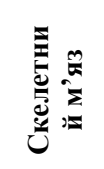 } & $\mathrm{Cd}^{2+}$ & $0,008 \pm 0,007$ & $0,011 \pm 0,007$ & $\begin{array}{c}0,025 \pm 0,005 \\
\mathrm{p}_{1}<0,02\end{array}$ & $\begin{array}{c}0,031 \pm 0,005 \\
\mathrm{p}_{1}<0,05\end{array}$ \\
\hline & $\mathrm{Pb}^{2+}$ & $0,026 \pm 0,008$ & $\begin{array}{c}0,115 \pm 0,017 \\
\mathrm{p}<0,001\end{array}$ & $0,035 \pm 0,003$ & $\begin{array}{c}0,125 \pm 0,004 \\
\mathrm{p}<0,001\end{array}$ \\
\hline
\end{tabular}

Примітки: $\mathrm{p}$ - ступінь вірогідності у порівнянні 3 контролем, $\mathrm{p}_{1}-$ ступінь вірогідності між показниками СН3 і С3 тварин.

За свинцевої інтоксикації, як і за кадмієвої, накопичення катіонів свинцю у тканинах СНЗ тварин відбувається інтенсивніше, ніж у С3. Уміст металу в нирках СН3 тварин зріс у 3,6 рази, у С3 - в 1,7 рази, у печінці СН3 - у 8,0 разів та у 3,9 рази у С3 тварин, відповідно. Градієнт тканинного розподілу свинцю засвідчив, що найбільше накопичення металу відбувається в нирках, а далі - у СНЗ тварин: мозок $=$ скелетний м'яз $>$ печінка $>$ серце, у С3 тварин нирки > печінка > скелетний м'яз = мозок > серце. 
Таким чином, незважаючи на деякі вікові відмінності у градієнті тканинного розподілу катіонів кадмію $\mathrm{i}$ свинцю, в організмі токсикованих тварин основними органами-мішенями, в яких накопичення катіонів металів найбільше, є печінка й нирки - саме ті органи, які причетні до детоксикації, елімінації та екскреції токсикантів, що, безумовно, не може не позначитися на їх функціональній діяльності. Отримані дані щодо більш інтенсивного накопичення катіонів кадмію і свинцю в нирках молодих щурів в умовах відповідного металотоксикозу узгоджуються з результатами інших дослідників ${ }^{13}$. Інтенсивніше накопичення катіонів ВM в організмі СНЗ тварин, імовірно, обумовлено кращою абсорбцією солі металу у травному каналі ${ }^{14}$, а також анатомічною незрілістю, незавершеністю процесів диференціювання клітин i тканин та недостатньою індукцією синтезу транспортних білків металотіонеїнів ${ }^{15}$.

Проведені патоморфологічні дослідження органів (нирки, печінка, серце, головний мозок, скелетний м'яз) щурів виявили патологічні зміни за умов кадмієвої інтоксикації в печінці у вигляді гідропічної дистрофії гепатоцитів, більш виразні у СНЗ тварин (рис. 1).

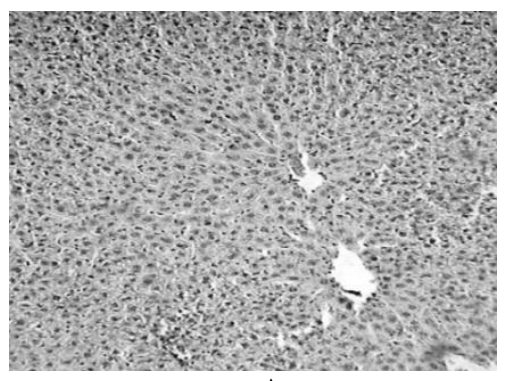

A

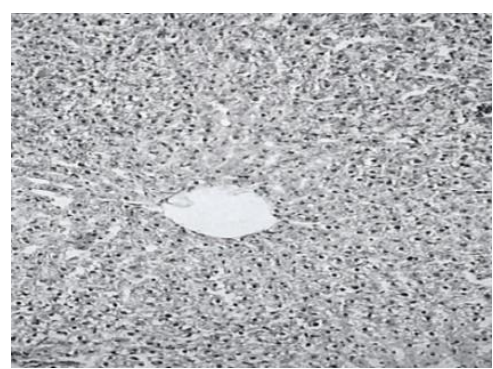

Б

Рис. 1. Морфологічна картина печінки експериментальних статевонезрілих щурів при забарвленні гематоксиліном й еозином: А - інтактні тварини, Б - після інтоксикації кадмію хлоридом. Об. $10^{10}$, Ок. $10^{10}$

13 Андрусишена I.M., Лампека О.Г. Особливості вікової зміни вмісту важких металів і мікроелементів в органах експериментальних тварин. Нариси вікової токсикології. Київ : Авіцена, 2005. С. 63-70.

${ }^{14}$ Микроэлементозы человека / А.П. Авцын и др. Москва : Медицина, 1991. $496 \mathrm{c}$.

${ }^{15}$ Шафран Л.М., Пыхтеева Е.Г., Большой Д.В. Металлотионеины. / под ред. Л.М. Шафран Одесса : Издательство “Чорномор'я”, 2011. С. 428. 
За свинцевої інтоксикації морфологічні зміни спостерігалися не лише в печінці, а й у нирках СН3 і С3 щурів у вигляді розсіяної дрібновогнищевої гідропічної дистрофії епітелію звивистих канальців (рис. 2).

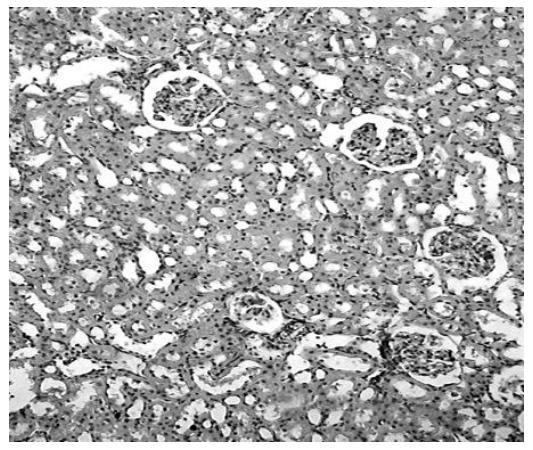

A

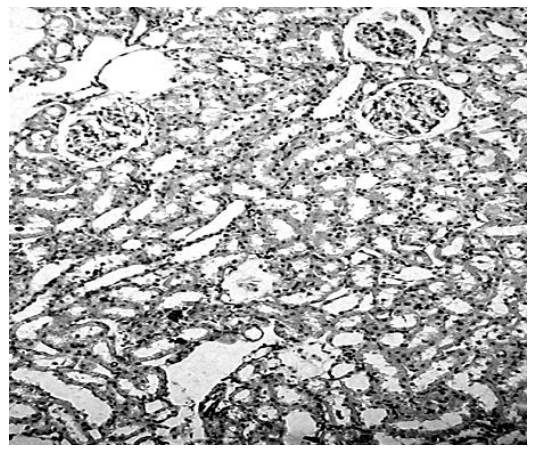

Б

Рис. 2. Морфологічна картина нирок СНЗ щурів при забарвленні гематоксиліном і еозином: А - інтактні тварини, Б - за дії свинцю ацетату. Об. $10^{x}$, Ок. $10^{x}$

Дослідження

циркадіанних

біоритмів

показників про/антиоксидантного гомеостазу в організмі тварин засвідчило деякі вікові відмінності у стані пероксидації та активності ферментів антиоксидантного захисту в інтактних тварин, що позначилося на їх реакції при адаптації до тривалого надходження ВМ (табл. 2). Як виявилося, процеси окиснення білків відбуваються i в організмі інтактних тварин, причому вміст окисно-модифікованих білків (ОМБ) у плазмі крові СН3 щурів на 13\% вищий, ніж у С3, що підтверджує дані літератури ${ }^{16}$. Перебіг біохімічних процесів в організмі щурів має циркадіанну періодичність та вікові особливості. Якщо біоритми ОМБ у СНЗ тварин характеризуються низькою амплітудою коливань i суттєво не змінюються впродовж доби, то у С3 тварин окислювальні процеси менш активні, амплітуда коливань циркадіанних біоритмів відносно мезору у 3,3 рази вища, ніж у СНЗ тварин, уміст ОМБ у плазмі крові має фотоперіодичну залежність.

16 Гонський Я. І., Ястремська С.О. Особливості окислювальної модифікації білків у тварин різних вікових груп при кадмієвій інтоксикації. Буковинський медичний вісник. 2005. № 9(2). С. 63-64 


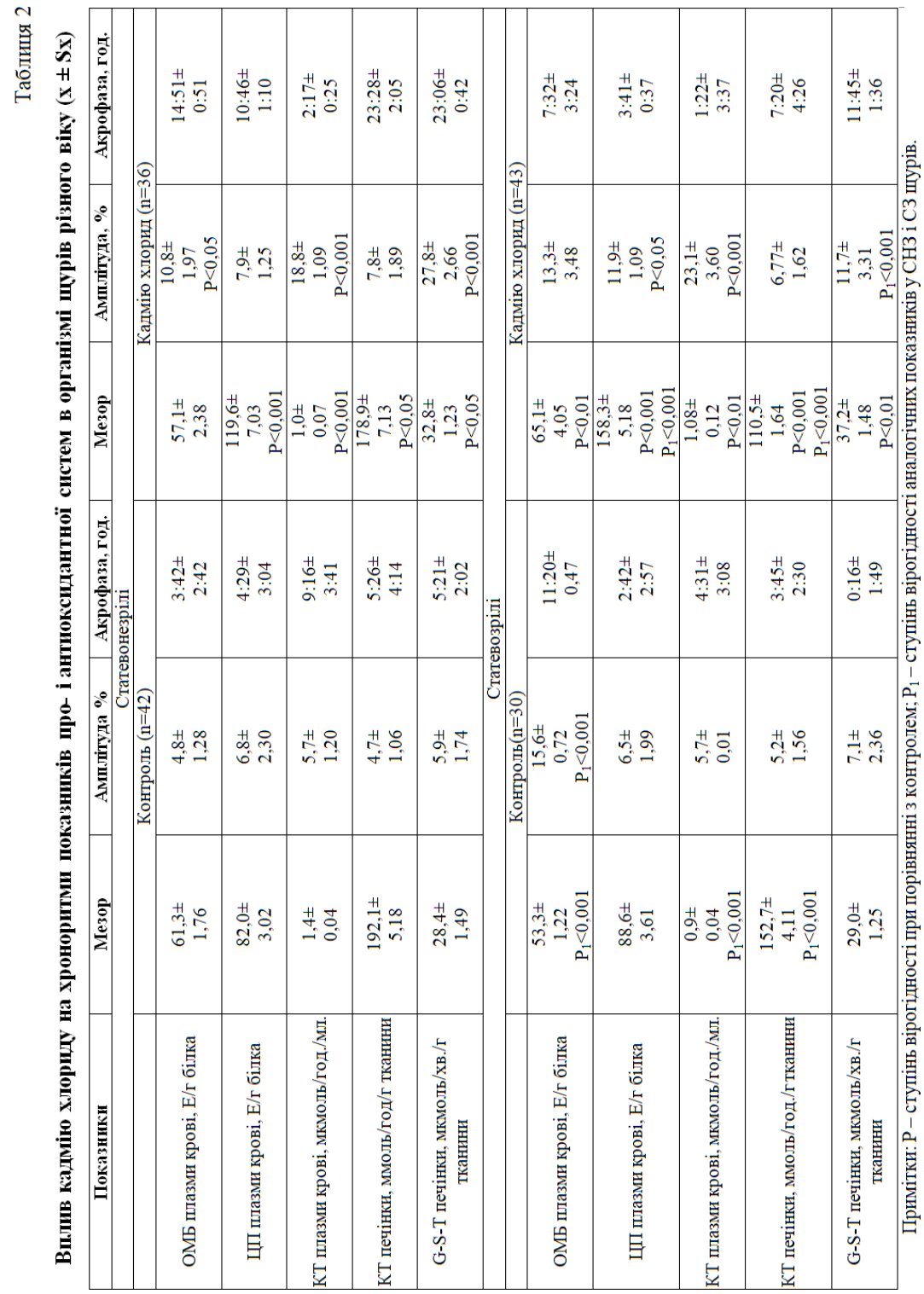


Батифаза вмісту ОМБ плазми крові С3 тварин припадає на період 3 $02^{00}$ год. ночі до $06^{00}$ год. ранку. Аналіз хронограм вмісту ОМБ у плазмі крові інтоксикованих ВМ тварин засвідчив, що відбулася перебудова структури біоритмів біохімічних показників, і він підтвердив наявне в літературі твердження, що кадмій і свинець $\epsilon$ прооксидантами ${ }^{1718} \mathrm{i}$, згідно 3 нашими дослідженнями, зумовлюють оксидативний стрес навіть при надходженні ВМ у дозах малої інтенсивності за тривалої їх експозиції. Так, середньодобовий рівень ОМБ у плазмі крові С3 тварин за дії кадмію хлориду зріс на 22\%, за свинцевої інтоксикації - на 23,7\%. Хоча у СНЗ тварин рівень ОМБ за дії металів суттєво не змінився, однак відбулися перебудови структури хроноритму.

При металотоксикозі виявлено активацію ферментів антиоксидантного захисту у відповідь на прооксидантну дію токсикантів, виразніше у С3 тварин (рис. 3). Уміст церулоплазміну (ЦП) у плазмі крові за свинцевої інтоксикації збільшився майже вдвічі, активність каталази (КТ) плазми крові зросла на 33\%. У СНЗ тварин мезор активності КТ, навпаки, зменшився. За дії свинцю ацетату у СНЗ тварин активність каталази печінки зросла на $18 \%$, у С3 тварин при більшій активності глутатіон-S-трансферази (G-S-T) - дещо знизилася. За кадмієвої інтоксикації активність КТ плазми крові зросла на $12 \%$, а активність КТ печінки зменшилася у тварин обох вікових груп, активність G-S-T зросла.

Збільшення активності ферментів антиоксидантного захисту $\epsilon$ захисною реакцією організму тварин на прооксидантну дію токсиканту, особливо у С3 тварин, однак, як свідчать наведені дані (рис. 3) ступінь виразності та архітектоніки хроноритмів відрізняються у тварин різного віку. Можна припустити, що за тривалої дії малих доз свинцю ацетату спостерігається напруження й активація адаптаційнокомпенсаторних механізмів організму, про що свідчать рівні показники та збільшення амплітуди біоритмів активності ферментів. У СН3 тварин, у яких вихідний рівень ОМБ вищий, ніж у С3, свинцева інтоксикація призвела до зменшення, виснаження ЦП й активності КТ у крові, хоча активність КТ печінки в них зросла, а у С3, навпаки, зменшилася. Збільшення мезора й амплітуди коливань біоритмів відносно мезора свідчать про виразнішу активність ферментів антирадикального захисту до адаптаційних процесів в організмі С3 тварин за умов інтоксикаціі.

17 Гонський Я.І., Чорна М.В. Динаміка вмісту активних форм кисню i вільнорадикального окиснення ліпідів та білків у щурів, уражених хлоридами кадмію та кобальту. Медична хімія. 2008. № 10(1). С. 102-105.

18 Трахтенберг И.М. и др. Свинец и окислительный стресс. Современные проблемы токсикологии. 2001 № 4, С. 50-53. 
Статевонезрілі

Статевозрілі

Вміст церулоплазміну (Е/1 г білка) у плазмі крові

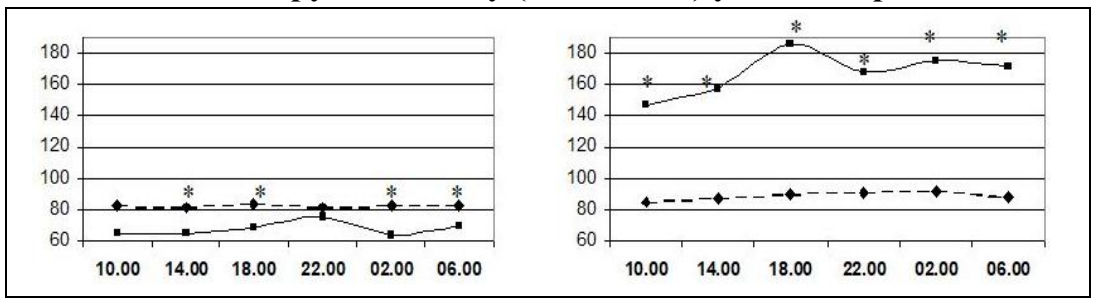

Активність каталази плазми крові (мкмоль/год/мл )

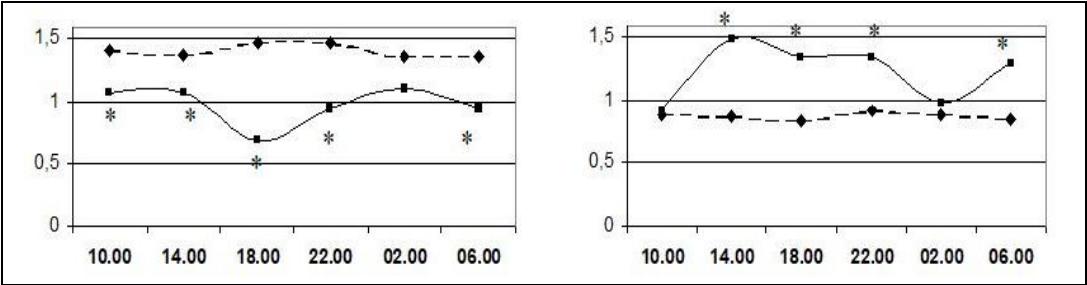

Активність каталази печінки (мкмоль/год/г тканини)

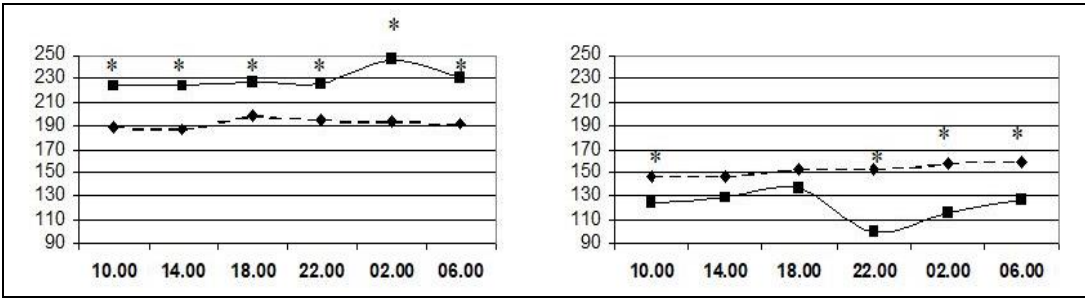

Активність глутатіон-S-трансферази печінки

(мкмоль/хв/г тканини)

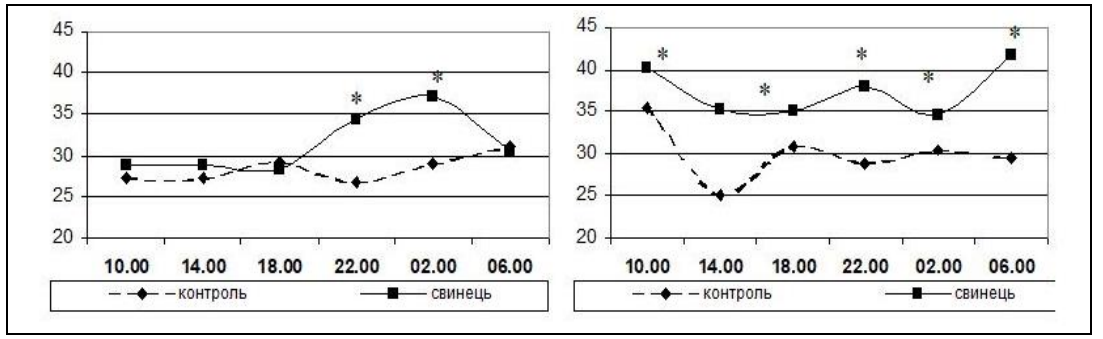

Рис. 3. Добова динаміка показників антиоксидантного захисту

плазми крові та гомогенатів печінки щурів різного віку за дії свинцю ацетату

Примітки: по осі ординат - показники, по осі абсцис - години доби. 


\section{2. Вікові особливості хронобіологічних ритмів ниркових функцій}

за умов кадмісвого та свинцевого металотоксикозу

Зважаючи на те, що у процесі онтогенезу всі види обміну речовин, функції нирок і систем зазнають кількісних і якісних змін, цілком імовірно передбачити, що і структура хроноритмів їх діяльності може суттєво змінюватися.

Перед дослідженням хроноритмологічної діяльності нирок за умов металотоксикозу нами вивчено аналогічні показники в інтактних СНЗ і С3 щурів, результати яких слугували в подальшому контролем. Виявилося, що показники, які характеризують екскреторну, іонорегулювальну, кислотнорегулювальну функції нирок у тварин обох вікових груп підпорядковані чіткій хроноритмологічній організації, мають циркадіанну періодичність і базуються на трьох основних ниркових процесах: клубочковій фільтрації, канальцевій реабсорбції та канальцевій секреції.

В основі хроноритмологічної діяльності нирок лежать узгоджені механізми клубочково-канальцевого, канальцево-канальцевого балансу та тубуло-гломерулярного зворотного зв'язку - синфазність циркадіанних ритмів фільтраційного заряду іонів натрію та його абсолютної реабсорбції, ідентичність хронограм абсолютної та стандартизованої за об’ємом клубочкового фільтрату екскреції іонів натрію. Антифазна структура хроноритмів екскреції іонів натрію й інтенсивності транспортних процесів у проксимальних канальцях та рівня його фільтраційної фракції відображає циркадіанну впорядкованість тубуло-гломерулярного зворотного зв'язку, які забезпечують збалансовану взаємодію фільтраційно-реабсорбційних процесів у нирках тварин. Добові ритми показників функції нирок відображають аналогічні зміни реальних процесів. У періоди низького рівня клубочкової ультрафільтрації зростає концентрація креатиніну у плазмі крові. Підвищення швидкості клубочкової фільтрації (КФ) призводить до підсилення діурезу. Циркадіанне співвідношення між процесами проксимального і дистального транспорту іонів натрію віддзеркалює фізіологічну взаємоузгодженість між облігатною та факультативною абсорбцією цього катіону. Добові показники кислотнорегулювальної функції нирок свідчать про активізацію процесів ацидогенезу в темний період доби.

Водночас у інтактних щурів, виявлено вікові особливості хроноритмологічної діяльності нирок. У процесі статевого дозрівання зазнають перебудови хроноритми екскреторної, іонорегулювальної i, меншою мірою, кислотнорегулювальної функцій нирок тварин. Хроноритм діурезу у СН3 і С3 щурів має синусоїдний характер із 
низькою амплітудою біоритму без суттєвих відмінностей мезора. Однак акрофаза сечовиділення у СН3 тварин припадає на $24^{00}$ ночі, батифаза $-304^{00}$ до $06^{00}$ год. ранку, у С3 тварин акрофаза - о $16^{00}$ год. дня, батифаза - з $20^{00}$ до $22^{00}$ год. ночі, відповідно (рис. 4).

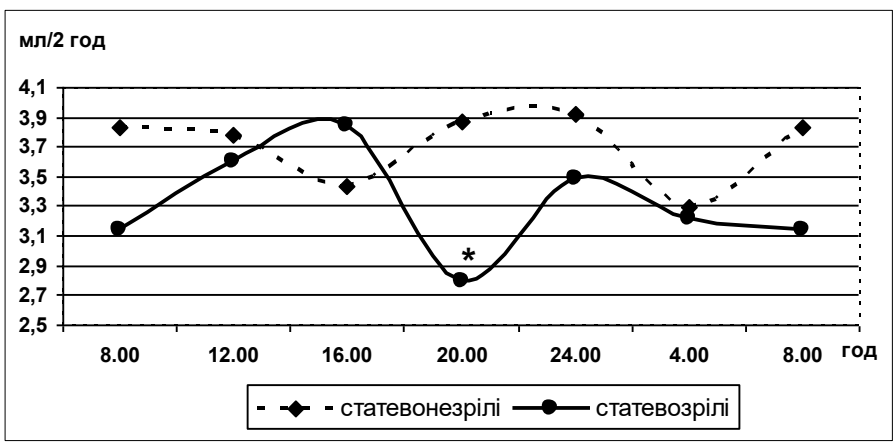

Рис. 4. Добовий хроноритм діурезу в інтактних щурів різного віку (мл/2 год/ 100 г)

Примітка: тут і далі вірогідність різниці * - p<0,05; ** - p<0,01; $* * *-\mathrm{p}<0,001$.

У СНЗ тварин, вірогідно, вищі мезори екскреції іонів калію і білка. 3 віком активується ретенція іонів натрію в організмі, зменшується амплітуда коливань, мезор ниркової екскреції іонів натрію у СЗ тварин в 2,7 раза нижчий, ніж у СНЗ тварин (рис. 5). Змінюється архітектоніка хроноритму натрійурезу, зростає реабсорбція іонів натрію в проксимальному відділі нефрону (табл. 3).

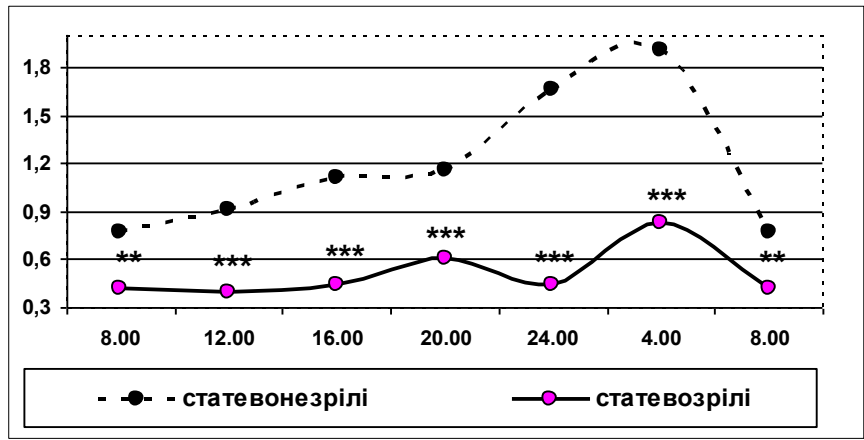

Рис. 5. Добовий хроноритм концентрації іонів натрію в сечі інтактних щурів різного віку (ммоль/л) 
Таблиця 3

Вікові особливості хроноритмів ниркового транспорту іонів натрію у щурів

\begin{tabular}{|c|c|c|c|c|c|c|}
\hline \multirow[b]{2}{*}{ Показники } & \multicolumn{3}{|c|}{ Статевонезрілі (n = 42) } & \multicolumn{3}{|c|}{ Статевозрілі (n = 30) } \\
\hline & Мезор & $\begin{array}{c}\text { Амплітуда, } \\
\%\end{array}$ & $\begin{array}{c}\text { Акрофаза, } \\
\text { год. }\end{array}$ & Мезор & $\begin{array}{c}\text { Амплітуда, } \\
\%\end{array}$ & $\begin{array}{l}\text { Акрофаза, } \\
\text { год. }\end{array}$ \\
\hline $\begin{array}{l}\text { Концентрація } \\
\mathrm{Na}^{+} \text {в сечі, } \\
\text { ммоль/л }\end{array}$ & $\begin{array}{l}1,25 \pm \\
0,222\end{array}$ & $\begin{array}{c}39,81 \pm \\
9,75\end{array}$ & $\begin{array}{c}2: 05 \pm \\
0: 51\end{array}$ & $\begin{array}{c}0,522 \pm 0,0 \\
704 * *\end{array}$ & $\begin{array}{c}27,03 \pm \\
2,34\end{array}$ & $\begin{array}{c}1: 58 \pm \\
0: 35\end{array}$ \\
\hline $\begin{array}{l}\text { Екскреція } \mathrm{Na}^{+} \\
3 \text { сечею, } \\
\text { мкмоль/2год }\end{array}$ & $\begin{array}{c}4,51 \pm \\
0,710\end{array}$ & $\begin{array}{c}42,04 \pm \\
5,45\end{array}$ & $\begin{array}{c}1: 12 \pm \\
0: 23\end{array}$ & $\begin{array}{c}1,70 \pm \\
0,198 * *\end{array}$ & $\begin{array}{l}20,31 \pm \\
5,84 * *\end{array}$ & $\begin{array}{c}1: 12 \pm \\
0: 47\end{array}$ \\
\hline $\begin{array}{l}\text { Ескреція } \\
\mathrm{Na}^{+} 3 \text { сечею, } \\
\text { кмоль/100 мкл } \\
\text { КФ }\end{array}$ & $\begin{array}{l}1,01 \pm \\
0,152\end{array}$ & $\begin{array}{c}32,49 \pm \\
5,61\end{array}$ & $\begin{array}{c}2: 54 \pm \\
1: 12\end{array}$ & $\begin{array}{c}0,37 \pm \\
0,050 * * *\end{array}$ & $\begin{array}{c}35,29 \pm \\
3,21\end{array}$ & $\begin{array}{c}2: 47 \pm \\
0: 19\end{array}$ \\
\hline $\begin{array}{l}\text { Концентрація } \\
\mathrm{Na}^{+} \text {в плазмі } \\
\text { крові, ммоль/л }\end{array}$ & $\begin{array}{c}126,1 \pm \\
1,07\end{array}$ & $\begin{array}{c}1,41 \pm \\
0,28\end{array}$ & $\begin{array}{c}4: 46 \pm \\
2: 23\end{array}$ & $\begin{array}{l}136,3 \pm \\
2,58 * * *\end{array}$ & $\begin{array}{c}4,22 \pm \\
0,56 * * *\end{array}$ & $\begin{array}{c}12: 13 \pm \\
1: 11\end{array}$ \\
\hline $\begin{array}{l}\text { Ескреторна } \\
\text { фракція } \mathrm{Na}^{+}, \\
\text {мкмоль/хв }\end{array}$ & $\begin{array}{c}0,036 \pm \\
0,0053\end{array}$ & $\begin{array}{c}38,41 \pm \\
5,76\end{array}$ & $\begin{array}{c}0: 41 \pm \\
0: 20\end{array}$ & $\begin{array}{c}0,014 \pm 0,0 \\
017 * * *\end{array}$ & $\begin{array}{c}21,18 \pm \\
6,35\end{array}$ & $\begin{array}{c}1: 14 \pm \\
0: 44\end{array}$ \\
\hline $\begin{array}{l}\mathrm{Na}^{+} / \mathrm{K}^{+} \\
\text {коефіцієнт, од. }\end{array}$ & $\begin{array}{c}0,115 \pm \\
0,0216\end{array}$ & $\begin{array}{c}36,48 \pm \\
7,21\end{array}$ & $\begin{array}{c}3: 14 \pm \\
1: 06\end{array}$ & $\begin{array}{c}0,069 \pm \\
0,0085\end{array}$ & $\begin{array}{c}30,43 \pm \\
4,49\end{array}$ & $\begin{array}{c}1: 24 \pm \\
0: 28\end{array}$ \\
\hline $\begin{array}{l}\text { Кліренс } \mathrm{Na}^{+} \text {, } \\
\text { мл/2 год }\end{array}$ & $\begin{array}{c}0,035 \pm \\
0,0050\end{array}$ & $\begin{array}{c}37,55 \pm \\
6,35\end{array}$ & $\begin{array}{c}0: 40 \pm \\
0: 20\end{array}$ & $\begin{array}{c}0,012 \pm \\
0,0017 * * *\end{array}$ & $\begin{array}{c}25,86 \pm \\
9,48\end{array}$ & $\begin{array}{c}3: 47 \pm \\
1: 22\end{array}$ \\
\hline $\begin{array}{l}\text { Проксимальни } \\
\text { й транспорт } \\
\mathrm{Na}^{+}, \\
\text {мкмоль/ } \\
100 \text { мкл КФ }\end{array}$ & $\begin{array}{l}11,7 \pm \\
0,129\end{array}$ & $\begin{array}{c}1,71 \pm \\
0,49\end{array}$ & $\begin{array}{c}1: 08 \pm \\
1: 24\end{array}$ & $\begin{array}{c}12,8 \pm \\
0,26 * * *\end{array}$ & $\begin{array}{c}4,59 \pm \\
0,43 * * *\end{array}$ & $\begin{array}{c}12: 36 \pm \\
1: 06\end{array}$ \\
\hline $\begin{array}{l}\text { Дистальний } \\
\text { транспорт } \\
\mathrm{Na}^{+}, \text {мкмоль/ } \\
100 \text { мкл КФ }\end{array}$ & $\begin{array}{c}0,876 \pm \\
0,0765\end{array}$ & $\begin{array}{c}19,29 \pm \\
3,78\end{array}$ & $\begin{array}{c}11: 08 \pm \\
1: 07\end{array}$ & $\begin{array}{c}0,83 \pm \\
0,067\end{array}$ & $\begin{array}{c}12,05 \pm \\
2,01\end{array}$ & $\begin{array}{c}4: 42 \pm \\
0: 59\end{array}$ \\
\hline
\end{tabular}

Примітка: вірогідність різниці показників у щурів різного віку.

Незважаючи на те, що мезори показників кислотнорегулювальної функції нирок у процесі статевого дозрівання суттєвих змін не зазнають, змінюється архітектоніка хроноритмів, активується екскреція 
іонів водню, зменшується екскреція іонів аміаку, що призводить до зниження $\mathrm{pH}$ сечі.

На тлі виявлених вікових особливостей циркадіанних біоритмів функцій нирок в інтактних тварин установлено, що тривале надходження низьких доз солей ВМ не тільки викликає перебудову хроноритмів, а й впливає на функціональний стан нирок у цілому. Хоча за інтоксикації кадмію хлоридом мезори діурезу у тварин обох вікових груп суттєво не змінюється, однак у СНЗ тварин у 2,3 рази зменшується амплітуда біоритму, акрофаза з ранкового часу зміщується на нічний. Поряд зі зниженням екскреції іонів калію у СНЗ тварин виявлено інверсію хроноритму: якщо в інтактних тварин о $20^{00}$ год. спостерігається найвищий показник біоритму (акрофаза), то за дії токсиканту в цей час концентрація іонів калію найнижча (батифаза) - в 2,6 рази менша, порівняно з контрольними тваринами. У С3 щурів за дії кадмію хлориду калійурез суттєво не змінився. У тварин відбулася депресія КФ із зниженням амплітуди біоритму i зміною фазової структури (рис. 6). Як прояв ретенційної азотемії, вдвічі збільшилася концентрація креатиніну в плазмі крові, амплітуда біоритму у С3 щурів зросла в 4,5 рази, акрофаза 3 денного часу змістилася на нічний. За кадмієвої інтоксикації мезор екскреції білка у СНЗ тварин зріс у 2,5 рази, у С3 - у 3,3 рази. Виявлене виразне збільшення мезору екскреції білка, зміщення акрофази біоритму з нічного періоду на денний та зменшення амплітуди біоритму засвідчили про значне порушення гломерулярно-тубулярних процесів ниркового транспорту протеїнів.

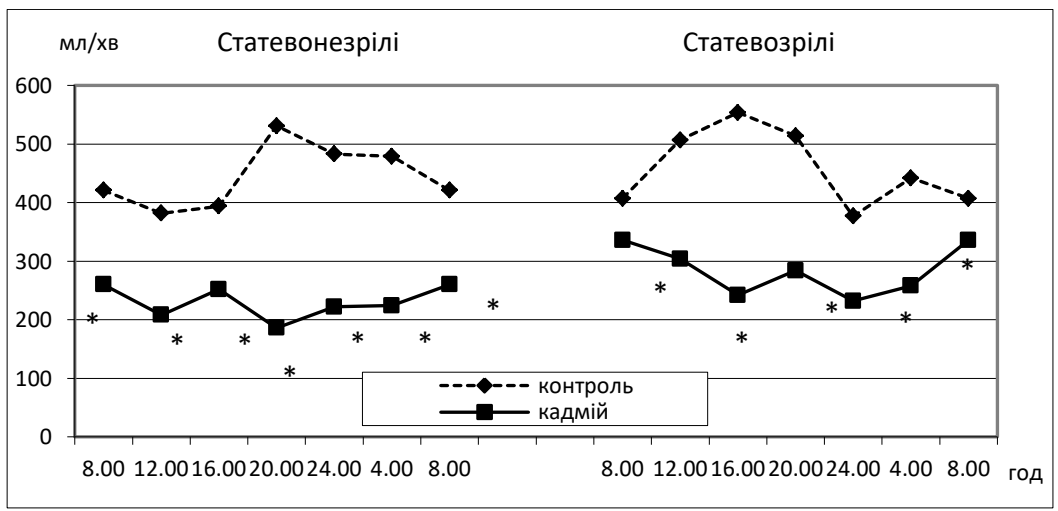

Рис. 6. Вплив кадмію хлориду на хроноритми швидкості клубочкової фільтрації (мл/хв) у щурів різного віку 
Ще більш помітних змін за дії кадмію хлориду зазнала іонорегулювальна функція нирок. У тварин обох вікових груп збільшився натрійурез, порушився добовий хроноритм ниркового транспорту іонів натрію, мезори концентрації та екскреції іонів натрію у СН3 і С3 тварин, вірогідно, різнилися. Стандартизовані показники натрійурезу відносно швидкості КФ зросли у СНЗ тварин у 2,8 рази, у С 3 - у 4,6 рази порівняно з контролем. Амплітуда біоритму натрійурезу у СН3 тварин зменшилася в 1,6 рази проти контролю, а у С3, навпаки, зросла втричі, що свідчить про більший ступінь напруженості адаптаційних процесів.

Порушилася структура хроноритму натрійурезу. Якщо на тлі кадмію хлориду у СНЗ тварин найвищий рівень виділення іонів натрію спостерігається в першій половині дня $\left(08^{00}-14^{00}\right.$ год.), і натрійурез перевищував контрольний показник у 2,6 рази, то у С3 - це був вечірній час $\left(20^{00}-22^{00}\right.$ год.), екскреція іонів натрію перевищувала показник в інтактних тварин у 6,6 рази. Підвищений кліренс іонів натрію у С3 тварин спостерігали впродовж доби, а у СНЗ тварин лише вранці. Значні втрати іонів натрію у С3 тварин призвели до зниження його концентрації у плазмі крові до рівня СНЗ тварин. Вірогідне зниження концентрації іонів натрію у плазмі крові тварин відбувалося в період найвищого натрійурезу. Змінилася архітектоніка хроноритмів: якщо у СНЗ тварин батифазу проксимального й акрофазу дистального транспорту іонів натрію спостерігали о $20^{00}$ год., то у С3 - вони припадали на $16^{00}$ год. (рис. 7).

Що стосується показників кислотнорегулювальної функції нирок, то у СН3 щурів зріс мезор $\mathrm{pH}$ сечі, знизилася екскреція іонів водню та титрованих кислот, зменшилася амплітуда їх біоритму відносно мезору i, як наслідок, зріс амонійний коефіцієнт, акрофаза його біоритму 3 нічного часу змістилася на ранковий. У С3 тварин активація адаптаційно-компенсаторних систем також призвела до залуження сечі.

Отже, на тлі кадмієвого металотоксикозу виник десинхроноз у процесі фільтрації та реабсорбції в ниркових канальцях СН3 і С3 тварин. Середньодобові рівні показників, значна варіабельність розташування акрофаз, зменшення амплітуд біоритмів у СНЗ тварин свідчать про менші можливості їх адаптаційно-компенсаторних систем і менш адекватну реакцію, порівняно зі С3 тваринами на тривале надходження токсичного агенту. 
Проксимальний транспорт $\mathrm{Na}^{+}$(мкмоль/100 мкл КФ)

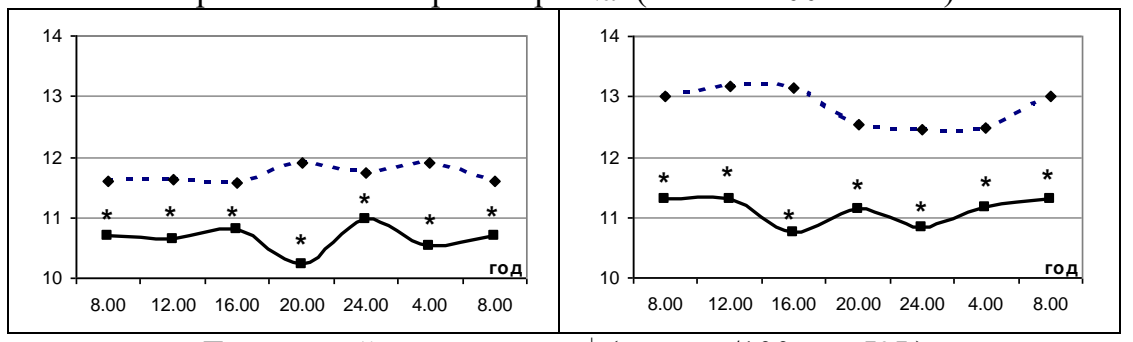

Дистальний транспорт $\mathrm{Na}^{+}$(мкмоль/100 мкл КФ)
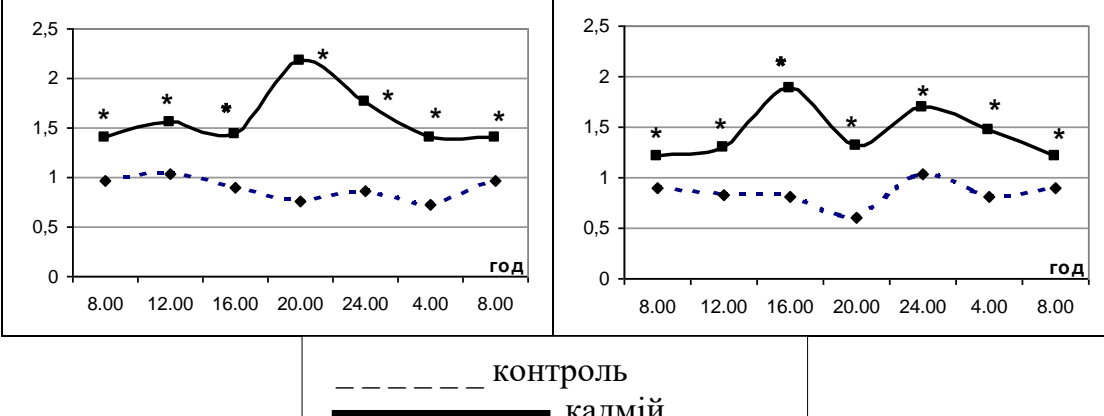

кадмій

Рис. 7. Добовий моніторинг транспорту іонів натрію (мкмоль/100 мкл КФ) у нефроні щурів різного віку за дії кадмію хлориду

За свинцевої інтоксикації також виявлено помітні прояви нефротоксичності металу як за характеристикою хроноритмів, так і за показниками функціонального стану нирок 3 наявністю вікових особливостей реагування. Якщо мезор діурезу у СЗ тварин суттєво не змінився, то у СН3 - зріс на 27\%. Збільшилась амплітуда калійурезу з порушенням фазової структури хроноритму у СНЗ тварин. Швидкість КФ зменшилася у СНЗ тварин в 1,6 рази, у С3 - в 1,3 рази, що призвело до ретенційної азотемії зі збільшенням концентрації креатиніну у плазмі крові СН3 тварин в 1,8 рази, у С3 - в 1,6 рази (рис. 8). Акрофаза біоритму швидкості КФ у СНЗ тварин із нічного часу змістилась на ранковий. Мезор стандартизованої щодо швидкості КФ екскреції білка з сечею у СНЗ тварин зріс у 9,4 рази, у С3 - в 3,5 рази. Мезор натрійурезу, стандартизований відносно швидкості КФ, у СНЗ тварин суттєво не змінився, у СЗ тварин за рахунок депресії реабсорбції у проксимальному відділі нефрону зріс у 
3,8 рази, що призвело до зменшення цього іону у плазмі крові. У тварин обох вікових груп активувався дистальний транспорт іонів натрію зі змінами у структурі хроноритмів.

\section{Статевонезрілі}

Статевозрілі

Швидкість клубочкової фільтрації, мкл/хв

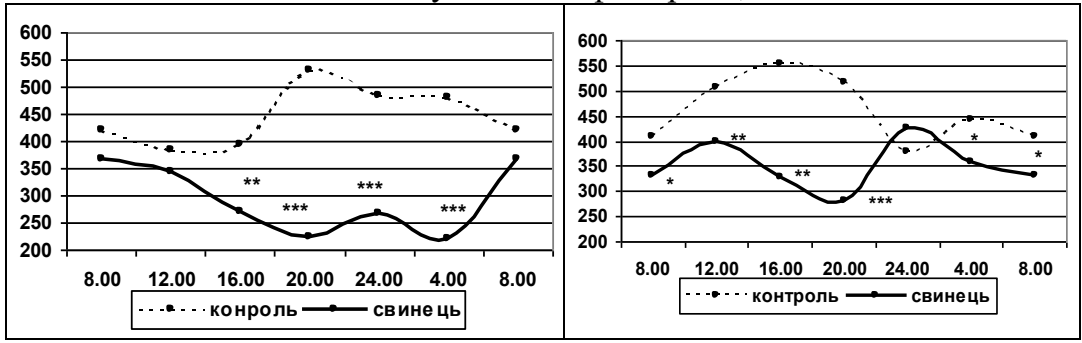

Концентрація креатиніну в сечі, ммоль/л
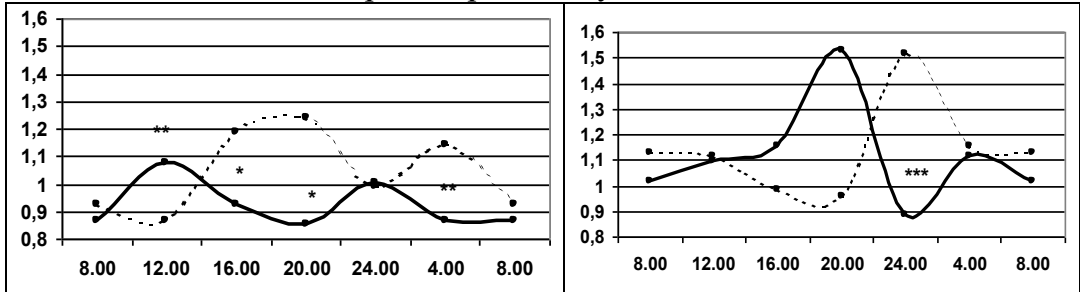

Рис. 8. Вікові особливості циркадіанних біоритмів швидкості клубочкової фільтрації та концентрації креатиніну у плазмі крові щурів різного віку за дії свинцю ацетату

Щодо показників кислотно-регулювальної функції нирок, то у СН3 тварин $\mathrm{pH}$ сечі не змінився, а у С3 внаслідок порушення натрійводневого котранспорту відбулося залуження сечі.

Отже, у СН3 і С3 щурів за тривалого надходження солей кадмію і свинцю в дозах малої інтенсивності виявлено явні ознаки нефротоксичності $\mathrm{BM}$, що узгоджується 3 чисельними даними літератури $^{19,20}$. Однак, поряд із класичними проявами нефропатії,

${ }^{19}$ Кириева Е.П., Кацнельсон Б.А., Дехтярева Т.Д. Нефротоксическое действие свинца, кадмия и его торможение комплексом биопротекторов. Токсикологический вестник. 2006. № 3. С. 26-32.

20 Кацнельсон Б.А., Привалова Л. И., Кузьмин С.В. Связь доклинических изменений в почках детей дошкольного возраста с содержанием кадмия и свинца в моче. Токсикологический вестник. 2006. № 4. С. 35-41. 
спостерігалися суттєві перебудови у хроноритмологічній організації діяльності нирок.

Виявлені нами окремі перебудови хроноритмів функцій нирок (зміщення положень акро- та батифаз, зростання амплітуди циркадіанних коливань) при збереженні синфазності взаємозалежних ниркових процесів і стабільності середньодобових значень показників можна трактувати як адаптаційно-компенсаторні реакції нирок на інтоксикацію, а інші явища десинхронозу - як результат нефротоксичності 3 розвитком декомпенсації. Безумовно, нефротоксичності сприяє накопичення ВМ у нирках тварин. Можливі різні механізми нефротоксичної дії ВМ, але наші дані свідчать, що одним із них $є$ активація прооксидантних процесів в організмі, збільшення вмісту ОМБ i, як наслідок, порушення основних ниркових процесів фільтрації і реабсорбції: зменшується швидкість КФ, зростають протеїнурія та екскреція іонів натрію.

Можна вважати, що центральною ланкою в патогенезі нефротоксичності малих доз солей кадмію і свинцю $є$ пошкодження механізмів реабсорбції іонів натрію у проксимальному відділі нефрону, що спричиняє активацію тубуло-гломерулярного зворотного зв'язку, шунтування ниркового кровотоку та ішемічну активацію перекисного окиснення ліпідів і білків. Ці спільні для кадмію і свинцю наслідки мають і свої особливості. За інтоксикації кадмію хлоридом переважають зміни в іонорегулювальній функції нирок, зокрема, в транспорті іонів натрію в нефроні. Порушення ниркового транспорту відбувається ще тоді, коли не виявлено патологічних змін у структурі основної функціональної одиниці нирок - нефроні, не порушився тубулогломерулярний зворотний зв'язок, оскільки поряд зі зменшенням процесів реабсорбції в проксимальному відділі нефрону зріс транспорт іонів натрію в дистальному його відділі і зменшилася фільтраційна фракція цього іону. За свинцевої інтоксикації, при якій поряд зі змінами в морфоструктурі печінки відбулися зміни в епітелії звивистих канальців нирок, спостерігалася більш виразна протеїнурія, що призвела до значної втрати білка організмом. Загалом, більш токсичним у наших дослідженнях виявився свинцю ацетат. Крім того, виявлено вікові відмінності нефротоксичності ВМ 3 огляду на онтогенетичні особливості ниркових функцій у СН3 і С3 щурів. Незважаючи на те, що в інтактних С3 тварин ретенція іонів натрію вища, ніж у СН3, оскільки у них уже сформовані нейрогуморальні механізми його регуляції, то за умов інтоксикації ВМ ниркові втрати іонів натрію щодо зменшеної швидкості КФ проявлялися більше натрійурез за кадмієвої інтоксикації зріс у 4,6 рази, за свинцевої - 
в 3,5 раз. У СН3 тварин, у яких натрійурез вищий, ніж у С3, при кадмієвій інтоксикації екскреція іонів натрію зросла в 2,8 рази, при свинцевій - змін не відбулося. У СНЗ тварин за вікової недосконалості фільтраційного фільтра клубочкового апарату нирок в інтактних тварин екскреція білка вища, ніж у С3, а за умов металотоксикозу зростає ще більше, особливо за свинцевого.

Поряд 3 особливостями нефротоксичності окремих ВM, найвиразніше вони проявилися при вивченні хроноритмів функцій нирок у віковому аспекті. Середньодобові рівні показників, значна варіабельність розташування акрофаз та зменшення амплітуди біоритму засвідчили виснаження й менші адаптаційно-компенсаторні можливості у СНЗ тварин, що проявилося в неадекватній їх реакції порівняно зі С3 тваринами на тривале надходження в організм токсичного агенту.

Разом із тим, не можна не зважати на загальну токсичну дію тривалого надходження солей ВМ, яка позначилася не лише на роботі нирок як ефекторного органу, а й інших органів, зокрема печінки, в якій відбувається значне накопичення ВМ, зменшується іiі білоксинтезуюча функція, змінюється амінокислотний склад крові, порушується функція печінки як органа детоксикації, оскільки блокада SH-груп ферментів зменшує їх активність ${ }^{21,22,23}$. Інтоксикація організму ВМ призводить до порушень функції органів і систем, які продукують нейрогуморальні та гормональні механізми регуляції водно-сольового обміну, під впливом яких відбуваються процеси в нирках. Зокрема, збільшені втрати організмом іонів натрію за умов інтоксикації ВМ можуть бути обумовлені зменшеною продукцією гормонів наднирниками ${ }^{24}$.

Виявлений очевидний характер патологічних порушень хроноритмологічної організації функції нирок, що спостерігається при

${ }^{21}$ Шепельова I.А., Деркач С.А., Мельникова Н.М. Амінокислотний склад крові та показники азотового обміну у щурів, отруєних кадмію сульфатом. Современные проблемы токсикологии. 2006. № 4, С. 35-37.

22 Гордієнко В.В. Особливості циркадіанних біоритмів показників про/антиоксидантного гомеостазу у статевонезрілих щурів за тривалої дії низьких доз кадмію хлориду. Медична хімія. 2014. № 16(3). С. 33-36.

${ }^{23}$ Гордієнко В.В., Бойчук Т.М. Вікові особливості гепатотоксичної дії кадмію хлориду у щурів за субхронічної експозиції доз малої інтенсивності. Буковинський медичний вісник. 2015. № 19(1). С. 45-48.

${ }^{24}$ Рогозина О.В., Озерова Н.Ю., Каширина Н.К. Морфология аденогипофиза и коры надпочечников при свинцовой интоксикации и ее коррекция. Світ медицини та біології. 2009. № 3(1). С. 136-140. 
інтоксикаціях солями кадмію i свинцю, потребує своєчасних й ефективних засобів їх попередження й корекції.

\section{ВИСНОВКИ}

Проведені нами дослідження щодо онтогенетичних особливостей перебудов хроноритмів функцій нирок за умов кадмієвої та свинцевої інтоксикації довели, що поряд зі зміною показників діяльності основних функцій нирок хронобіологічні характеристики $є$ найбільш значущі й виявляються раніше, ніж класичні ознаки нефротоксичності. Це дозволяє розглядати їх як найбільш чутливі маркери ушкодження нирок, що може виявити особливості розвитку патологічних процесів ще на початкових етапах захворювання. Поряд з урахуванням вікових особливостей хроноритмологічної організації діяльності нирок, як узагальнення отриманих даних можна сформулювати концепцію екозалежної хронопатології таким чином:

1. Висока амплітуда циркадіанного біоритму характеризує нестабільність i напруження гомеостатичних механізмів при максимальному ступені мобілізації їх функціональних резервів.

2. Збільшення амплітуди 3 порушенням фазової структури біоритму відображають компенсаторну реакцію організму на екологічно шкідливе навантаження.

3. Мезор $\epsilon$ інтегральною характеристикою біоритму й не віддзеркалює реального стану ранніх патологічних змін циркадіанної організації організму.

4. Важливим критерієм екопатологічного десинхронозу $\epsilon$ порушення симетричності функціонально залежних гомеостатичних процесів із формуванням дисфазності, крайнім проявом якої є інверсія біоритму.

5. Різке зниження амплітуди циркадіанного ритму з порушенням розподілу акро- та батифаз є станом циркадіанної ареактивності i свідчить про важкий десинхроноз із втратою біосистемою компенсаторних резервів.

Такий очевидний характер патологічних порушень хроноритмологічної організації функцій нирок і систем організму, що спостерігається при інтоксикаціях важкими металами, потребує своєчасних та ефективних засобів їх попередження та корекції.

\section{АНОТАЦІЯ}

У монографії наведено теоретичне узагальнення та нове вирішення наукового завдання щодо встановлення вікових особливостей токсичного впливу на організм і хроноритмологічну організацію 
функцій нирок (екскреторної, іоно- та кислотнорегулювальної) за субхронічної інтоксикації малими дозами кадмію хлориду і свинцю ацетату. У першому параграфі наведено результати системного дослідження субхронічної інтоксикації статевонезрілих (1,5 міс.) та статевозрілих (5 міс.) щурів солями важких металів - кадмію хлориду, свинцю ацетату в дозах малої інтенсивності на показники загального стану організму тварин (маса тіла, масові коефіцієнти внутрішніх органів, розподіл і накопичення ВМ у тканинах, морфоструктура органів, стан про/антиоксидантного гомеостазу в хронобіологічному аспекті). Вразливішими до дії екотоксикантів виявилися щури в період статевого дозрівання. У другому параграфі вперше доведено наявність вікових особливостей хроноритмологічної організації екскреторної, іонорегулювальної та кислотнорегулювальної функцій нирок в інтактних тварин та за субхронічної інтоксикації солями кадмію та свинцю. За свинцевого та кадмієвого металотоксикозу виникає десинхроноз інтегральних характеристик хроноритмів фільтраційнореабсорбційних процесів, порушуються механізми клубочковоканальцевого балансу та тубуло-гломерулярного зворотного зв'язку, що супроводжується депресією швидкості клубочкової фільтрації, порушенням натрій-водневого котранспорту, втратою іонів натрію, азотемією та протеїнурією. Аналіз циркадіанних біоритмів функціонального стану нирок засвідчив менші компенсаторні можливості статевонезрілих тварин до екологічно шкідливого навантаження. Перебудова хроноритмів основних функцій нирок виникає раніше, ніж класичні ознаки нефротоксичності, що дозволяє розглядати їх як найбільш чутливі маркери пошкодження нирок на ранніх етапах розвитку патологічного процесу.

\section{ЛІТЕРАТУРА}

1. Повякель Л.І. та ін. Важкі метали як фактор ризику для здоров'я людини та довкілля при поводженні 3 відходами електричного та електронного обладнання (огляд літератури). Сучасні проблеми токсикології, харчової та хімічної безпеки. 2015. № 1-2, С. 41-49.

2. Арустамян О.М., Ткачишин В.С., Алексійчук О.Ю. Вплив сполук кадмію на організм людини. Медицина неотложных состояний. 2016. № 7. C. 109-114.

3. Апихтіна О.Л., Козлов К.П. Динаміка накопичення кадмію у внутрішніх органах щурів після тривалого введення хлориду кадмію та наночастинок сульфіду кадмію різного розміру. Медичні перспективи. 2017. № 22(2), C. 4-9. https://doi.org/10.26641/2307-0404.2017.2.109707. 
4. Трахтенберг I.M. Токсичність і вік: проблема стара та нова. Нариси вікової токсикології. Київ : Авіцена, 2005. С. 10-17.

5. Трахтенберг И.М., Коршун М.Н., Вербилов А.А. Возрастные особенности развития адаптации к токсическим воздействиям. Очерки возрастной токсикологии. Киев : Авиценна, 2006. С. 34-40.

6. Пішак В.П., Булик Р.С. Молекулярно-генетичні маркери циркадіанних ритмів за фізіологічних умов. Буковинський медичний вісник. 2010. № 14(2). С. 12-19.

7. Рапопорт С.И., Фролов В.А., Хетагурова Л.Г. Хронобиология и хрономедицина : руководство. Москва : ООО "Медицинское информационное агентство", 2012. 480 с.

8. Хронофармакология для врача, провизора и студента : учебниксправочник / под ред. С.М. Драговоз. Харьков : “Титул”, 2016, 376 с.

9. Кухарчук О.Л., Кокощук Г.І., Чала К.Н. Вплив гострої затравки щурів хлористим кадмієм на екскреторну функцію нирок за умов водного навантаження. Буковинський медичний вісник. 2001. № 5(2), C. $185-188$.

10. Янчук В.В., Власик Л.І. Вікові особливості розвитку хроноконцентраційного ефекту під впливом смертельних доз натрію нітрату та свинцю ацетату. Современные проблемы токсикологии. 2001. № 4. C. 37-38.

11. Антоняк Г.Л. та ін. Екотоксикологічні аспекти впливу кадмію на організм людини і тварин. Медична хімія. 2007. № 9(3), С. 112-119.

12. Зербино Д.Д., Соломенчук Т.М. Свинец: поражения сосудистой системы. Український медичний часопис. 2002. № 2(18), С. 79-83.

13. Андрусишена I.М., Лампека О.Г., Особливості вікової зміни вмісту важких металів і мікроелементів в органах експериментальних тварин. Нариси вікової токсикології. Київ : Авіцена, 2005. С. 63-70.

14. Микроэлементозы человека / А.П. Авцын. и др. Москва : Медицина, 1991. $496 \mathrm{c.}$

15. Металлотионеины / Л.М. Шафран и др. ; под ред. Л.М. Шафран. Одесса : “Чорномор'я”, 2011, 428.

16. Гонський Я.І., Чорна М.В. Динаміка вмісту активних форм кисню і вільнорадикального окиснення ліпідів та білків у щурів, уражених хлоридами кадмію та кобальту. Медична хімія. 2008. № 10(1), C. $102-105$.

17. Трахтенберг И.М. и др. Свинец и окислительный стресс. Современные проблемы токсикологии. 2001 № 4, С. 50-53.

18. Кириева Е.П., Кацнельсон Б.А., Дехтярева Т.Д. Нефротоксическое действие свинца, кадмия и его торможение комплексом биопротекторов. Токсикологический вестник. 2006. № 3. С. 26-32. 
19. Кацнельсон Б.А., Привалова Л.И., Кузьмин С.В. Связь доклинических изменений в почках детей дошкольного возраста с содержанием кадмия и свинца в моче. Токсикологический вестник. 2006. № 4. C. $35-41$.

20. Гордієнко В.В. Вікові особливості хроноритмів вільно радикальних процесів та ферментів антиоксидантного захисту у щурів за умов тривалої дії малих доз свинцю ацетату. Буковинський медичний вісник. 2005. № 9(2), С. 67-70.

21. Гордієнко В.В. Особливості циркадіанних ритмів показників про/антиоксидантного гомеостазу у статевонезрілих щурів тривалої дії низьких доз кадмію хлориду. Медична хімія. 2014. № 16(3). С. 33-36.

22. Шепельова I.А., Деркач Є.А., Мельникова Н.М. Амінокислотний склад крові та показники азотового обміну у щурів, отруєних кадмію сульфатом. Современные проблемы токсикологии. 2006. № 4. С. 35-37.

23. Рогозина О.В., Озерова Н.Ю., Каширина Н.К. Морфология аденогипофиза и коры надпочечников при свинцовой интоксикации и ее коррекция. Світ медицини та біологіï. 2009. № 3(1). С. 136-140.

\section{Information about authors:} Gordienko V. V.,

Candidate of Medical Science, Associate Professor, Associate Professor of Department of Physiology Bukovinian State Medical University 2, Teatralna Sq., Chernivtsi, Ukraine

Perepelytsya O. O., Candidate of Biological Science, Associate Professor, Associate Professor of Department of Medicinal and Pharmaceutical Chemistry Bukovinian State Medical University 2, Teatralna Sq., Chernivtsi, Ukraine 